\title{
The Use of SEM-EDX Investigations in Estimating The Penetration Depth of Preparation Layers Within Wood Structure
}

\author{
Safa A. M. Hamed ${ }^{\text {a }}$ \& Nesrin M. N. El Hadidi ${ }^{\text {a }}$ \\ Conservation Department, Faculty of Archaeology, Cairo University, 12613 Giza, Egypt.
}

\section{HIGHLIGHTS}

- Investigating wood samples covered with preparation layers, similar in composition to ancient paint grounds

- Assessment the penetration depth of preparation layers -inside native Ficus sycomorus (sycomore fig), Tamarix sp. (tamarisk wood) and Acacia sp. (acacia wood) after subjecting to natural and accelerated aging.

- Determination of the factors on which penetration of the preparation layers within wood structure depend on.

- Elemental analysis of the seven wooden samples of each of the three wood types was conducted.

\begin{tabular}{l}
\hline ARTICLE INFO \\
\hline Article History: \\
Received: 15 February 2020 \\
Revised: 10 May 2020 \\
Accepted: 6 September 2020 \\
Available online: 7 September 2020
\end{tabular}

Keywords:

SEM-EDX; wood; preparation layers; penetration; elemental analysis.

\section{GRAPHICAL ABSTRACT}

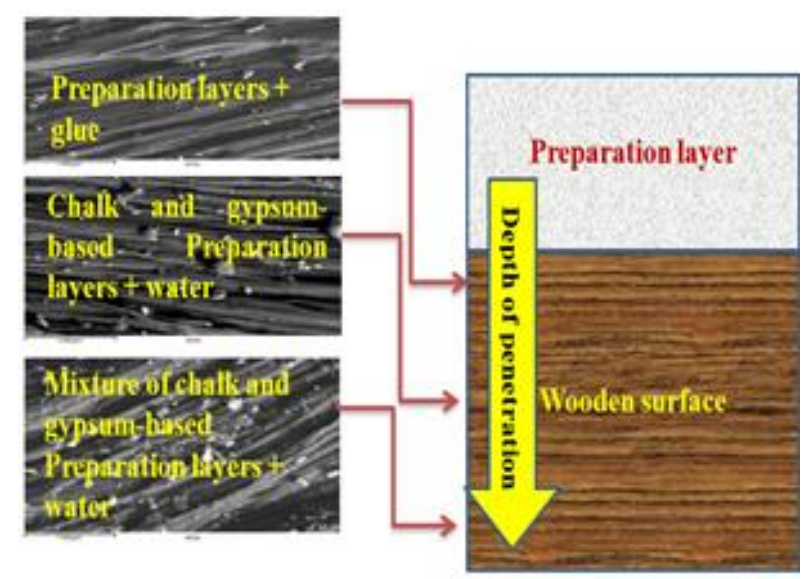

\footnotetext{
* Corresponding author: Safa_an78@yahoo.com
} 
For investigation and analysis, samples were taken from the wood at a depth of $5 \mathrm{~mm}$ directly below the substrate, after exposing the samples to natural and accelerated (light and heat) aging, which simulated partially the natural ageing process of ancient Egyptian artifacts. Results of investigation and analysis were compared with results obtained from the control wood samples that had not been covered with any preparation layers. The results concluded that penetration of preparation layers inside the wood structure is totally dependent on three factors; first, the wood type which differed in pore size, second, the mineralogical composition of the preparation layer applied on the wood, and third the binding medium used.

\section{Introduction}

Over the centuries preparation layers have always been used to cover wood for decorative purposes in Egyptian artifacts or architectural elements, such as ceilings and domes. Also, medieval churches contain a variety of polychrome wooden sculptures and ceilings [1, 2]. Polychromatic surface was a decorative technique that involved the application of pigments over layers of ground, which consisted of various materials known as preparation layers [3, 4]. The composition of these layers varied and so did the type of wood substrate [5]; forming multi layered composite structure. Each and every layer of polychrome wooden artifacts has different physical and chemical properties, and the addition of a binding media also plays an important role during application. Chemical reactions occur during the preparation process, but at some point the artifact reaches a certain equilibrium state. As long as environmental conditions remain unchanged the different layers are stable; yet any change in conditions will result in alterations in the layers $[1,5]$, which are one of many reasons for the state in which the artifacts have reached us today. Therefore it is not only the material or individual wooden element that has to be studied, but also the structure as a whole; especially because preparation layers can often be detected while examining wood in a lot of archaeological artifacts in museums and monuments [6].
Carbon, hydrogen, oxygen and small amounts of nitrogen are the main elements that form the main wood components. Other elements, such as calcium, are present if crystals are naturally formed within the cell walls. Some species of Acacia sp., Ficus sp. and Tamarix sp. contain crystals within the parenchyma cells and rays. Acacia crystals are presumed to be composed of calcium oxalate, which is a reason for the presence of calcium in that type of wood [7]. Calcium is also a main component in preparation layers composed of either chalk or gypsum, making the interpretation of elemental analysis of wood slightly confusing .

Few researches were done to study the preparation layers that were used to cover the wooden supports, their composition and their impact on each other [8]. Wood, like any other organic material is perishable, yet if kept in dry conditions; it can remain in relatively good conditions, not only for centuries, but also millennia. There are very good examples of wooden boats dating back to the first Dynasty from Abu Rawash in Egypt, where the wood had been buried in the sand at a depth of approximately 50 centimeters for almost 5000 years. Although the wood had been exposed to daily temperature fluctuations, rain, insect infestation and microbial decay during its years of burial, yet it the main wood carving techniques were technically visible [9]. If the Abu Rawash boat had been kept in an intact burial pit, such as the boat of Che- 
ops, which remained buried for around 4500 years [10], the wood would not have deteriorated that badly. Ancient Egyptian polychrome artifacts have been exposed to various factors, exactly like the above mentioned examples, therefore their state of preservation varies according to burial conditions, and it is extremely difficult to treat any of these artifacts alike, because each one decays in a different manner .

For this paper it was necessary to eliminate the different deteriorating factors, and concentrate only on one general point that has affected the wood surface throughout Egyptian history since the introduction of polychromy in the early dynasties, namely the components that were used to cover the wood, that has remained almost intact inside the burial chambers. The aim of this research is to look closely at how deep the components of preparation layers penetrate the surface of three types of native Egyptian wood types commonly used throughout history in furniture making and structural assemblies in buildings.

\section{Materials and methods}

\subsection{Samples:}

Samples (approx. 1 x 1 x $2 \mathrm{~cm}$ ) had been cut out of wood, each of which had been previously coated with a thin layer of one of six different preparation layers prepared for the preliminary study that focused on the effects of preparation layers on three native Egyptian wood types commonly identified in artifacts dating back to different eras. These previously prepared samples, composed of Ficus sycomorus (sycomore fig), Tamarix sp. (tamarisk wood) and Acacia sp. (syn. Vachellia sp, acacia wood) had been covered with preparation layers that consisted of commercially available hydrated calcium sulphate $\left(\mathrm{CaSO}_{4} \cdot 2 \mathrm{H}_{2} \mathrm{O}\right)$, and lime plaster or calcium carbonate $(\mathrm{Ca}-$ $\mathrm{CO}_{3}$ ) [8]. Throughout history wood was usually cut along the grain, and from workshop scenes, it is assumed that the timber $\operatorname{logs}$ were plain sawn. Usually the tangential plane or surface of the wood would have been covered with the preparation layers, and accordingly the tangential surface of all experimental samples was covered with the preparation layers.

Samples of untreated wood were the control samples and both their structure and chemical composition were referred to for interpretation of results. The six preparation layers were divided into 3 main types;

Type one: Preparation layer containing calcium carbonate

Type two: Preparation layer containing gypsum

Type three: Preparation layer containing a mixture of $85 \%$ calcium carbonate and $15 \%$ gypsum

All wood surfaces were wetted prior to application of the preparation layer. Each type of preparation layer was prepared once by mixing with water only and once by mixing with an animal glue solution (1glue: 15 water $\mathrm{v} / \mathrm{v}$ ), then the three wood types were covered with all six preparation layers, making a total of 18 different samples.

\subsection{Accelerated Aging}

There is so far no standard for accelerated ageing, which would simulate the various decay factors that affect ancient Egyptian wooden artifacts, therefore the following procedure was conducted to trigger off decay similar to what may happen in an artifact during its early years of burial. The blocks were stored for a total of three years in a lab (normal weather conditions in Greater Cairo). After that period the samples were exposed to two artificial ageing procedures. Firstly, they were light aged by exposure for 5 hours to UVA (4.465 $\left.\mathrm{mW} / \mathrm{cm}^{2}\right)$ and UVC $\left(2.394 \mathrm{~mW} / \mathrm{cm}^{2}\right)$ at a stable temperature of $25.5 \pm 11^{\circ} \mathrm{C}$ and relative humidity $32 \pm 4$ $\%$. Secondly, they were heat aged in 
Binder 924030000200 oven for 240 hours at $80^{\circ} \mathrm{C}$ and $65 \% \mathrm{RH}$.

\subsection{Scanning (SEM) and Environ- mental Scanning Electron Mi- croscope (ESEM) and EDX}

The reason for choosing this investigative method is that most of the research conducted on archaeological samples depends heavily on this method, and for comparison in future research it is necessary to have images taken at different magnifications with a scanning electron microscope. A total of 21 wood samples were studied using scanning electron microscope (SEM) and environmental scanning electron microscope (ESEM). The preparation layer was carefully removed from the wood, without causing any abrasion to the surface.

For SEM the samples were mounted on aluminum stubs with double-sided cellophane tape. After gold coating using a Polaron sputter coater, the samples were examined by SEM (JEOL scanning electron microscope JXA-840A). The SEM study was performed to document the wood interface surface that lay beneath the preparation layers.

ESEM samples were small pieces of an appropriate size from wood taken at a depth of $5 \mathrm{~mm}$ from the wood interface. The samples were prepared by fixing them on stubs with double-sided cellophane tape and examined using a Quanta 250FEG ESEM. The ESEM study was performed to monitor gesso layer particles and their interaction after penetration in the wood samples. The elemental composition of the particles that penetrated within the wood structure was analyzed using an EDX Ametek Octane Pro. EDX was used to examine and compare the elemental composition of three types of wood covered with six different preparation layers at a depth of $5 \mathrm{~mm}$ from the wood surface in the tangential direction of: 1) Acacia wood samples; 2) Sy- comore wood samples; 3) Tamarix wood samples. Elemental analysis of the seven wood samples (control and 6 samples covered with preparation layer) of each of the three wood types was conducted, which formed a total of 21 results.

The percentage of four elements: Carbon (C), Oxygen (O), Sulphur (S) and Calcium (Ca) was compared in all wood samples covered with preparation layers with the control sample of each wood type.

\subsection{Statistical analysis}

The changes in the elemental composition of wood samples covered with different preparation layers were analyzed using SPSS (Statistical Package for Social Sciences) for Windows, version 22 (IBM, Inc.). The group comparison of all samples was done using repeated measures analysis of variance (ANOVA) to detect overall differences between the means of the outcome measures for all samples. For all measures, the significance was set at an alpha level of 0.05 , and the data are presented as means and standard deviations (SDs).

\section{Results and discussion}

\subsection{SEM investigation:}

In a previously published preliminary study the effects of the preparation layers had been observed and documented, and several changes were recorded [8]. The changes were not as drastic as the changes that are often observed in some of the ancient artifacts, therefore it was necessary to reinvestigate the same samples after ageing and compare results. SEM micrographs of the surface of all three wood types after natural aging clearly indicate the differences in distribution of the six different preparation layers on the tangential surface of the wood, which is considered the interface between the wood and any preparation layer (Figs. 1, 
2, and 3). The chalk and gypsum particles were clearly noticeable on the cell walls and filled the cavities in an inconsistent manner in the three wood types. The preparation layer composed of chalk, gypsum and glue layer gave the best coverage in all three wood types (Fig.1f, 2f, 3f), and sycomore samples showed the best coverage of preparation layers in comparison to the other wood types (Fig. 2 ), and the contraction of the preparation layer of chalk and chalk mixed with glue, was most prominent in the sycomore wood (Fig. 2a, d).

After accelerated ageing of the samples, the aim of which was to expose the samples to deteriorating factors that simulated some of the burial conditions to which artifacts are exposed, the samples were studied at a depth of $5 \mathrm{~mm}$ from the wood surface that had been previously covered with preparation layers. In general, the microscopic observations revealed that the penetration of preparation layer particles within wood structure was much higher in sycomore wood (Fig.5) in comparison to acacia and tamarix wood samples (Fig. 4, 6). The preparation layers in which glue was used as a binding medium penetrated less in all wood samples, with an exception in the sycomore sample that was covered with chalk and glue (Fig. 5c) where cell wall erosion occurred due to the presence of chalk. Therefore, we may assume from our observations that glue reduces the penetration of the preparation layers due to the higher viscosity of the mixture.

Significant differences were noticed within the three wood types. SEM micrographs of acacia wood showed that all types of preparation layers penetrated within acacia wood structure (Fig. 4), but those based on a mixture of chalk and gypsum penetrated in depth and their effect on wood deterioration was very obvious (Fig. 4f, g). It was noticed that all the preparation layers penetrated in a similar way in sycomore wood (Fig. 5), while their impact on the wood structure was more evident in the samples covered with gypsum-based layers where the disintegration of wood cells in these samples was clearly obvious (Fig. 5d, e). In tamarix wood samples, the penetration of preparation layers was almost alike in all samples (Fig. 6). Whereas, the resulting deterioration was clearly apparent in the samples covered with gypsum-based layers (Fig. 6d, e) and mixture of chalk and gypsum-based layers (Fig. 6f, g).

These findings can be explained by looking closely at the anatomical structure of the three hardwood types which have similar cell types, but differ in vessel diameter and vessel frequency per $\mathrm{mm}^{2}$. They are not only different from one genus to the other, but they can vary from one species to the other within the same genus. For example the radial diameter of the vessel cells in various sycomore species ranges between 117-176 $\mu \mathrm{m}$ and the vessel frequency ranges between $4-13$ / $\mathrm{mm}^{2}$ [11]. In the case of acacia: The radial diameter of the vessels in Acacia gerrardii is $100-120 \mu \mathrm{m}$ for small vessels and 180-200 $\mu \mathrm{m}$ for large vessels [12], but for Acacia nilotica the radial diameter of the vessel is $175 \mu \mathrm{m}$ and the vessel frequency of is ca. $4-5 / \mathrm{mm}^{2}$. In the case of Tamarix aphylla the radial diameter of the vessel is $111 \mu \mathrm{m}$ and vessel frequency is around $11 / \mathrm{mm}^{2}$ [13].

These differences help explain the high variation in penetration percentage of both calcium and sulphate within the three types of wood. In addition to the previous facts, it is necessary to point out that the specific gravity of sycomore is 0.47 [14], acacia 0.61 and tamarix 0.55 [13] indicating a difference in porosity of the three wood types, which is another main factor that helps in the penetration of any type of moisture containing small particles to move lengthwise and sidewise inside the wood. 

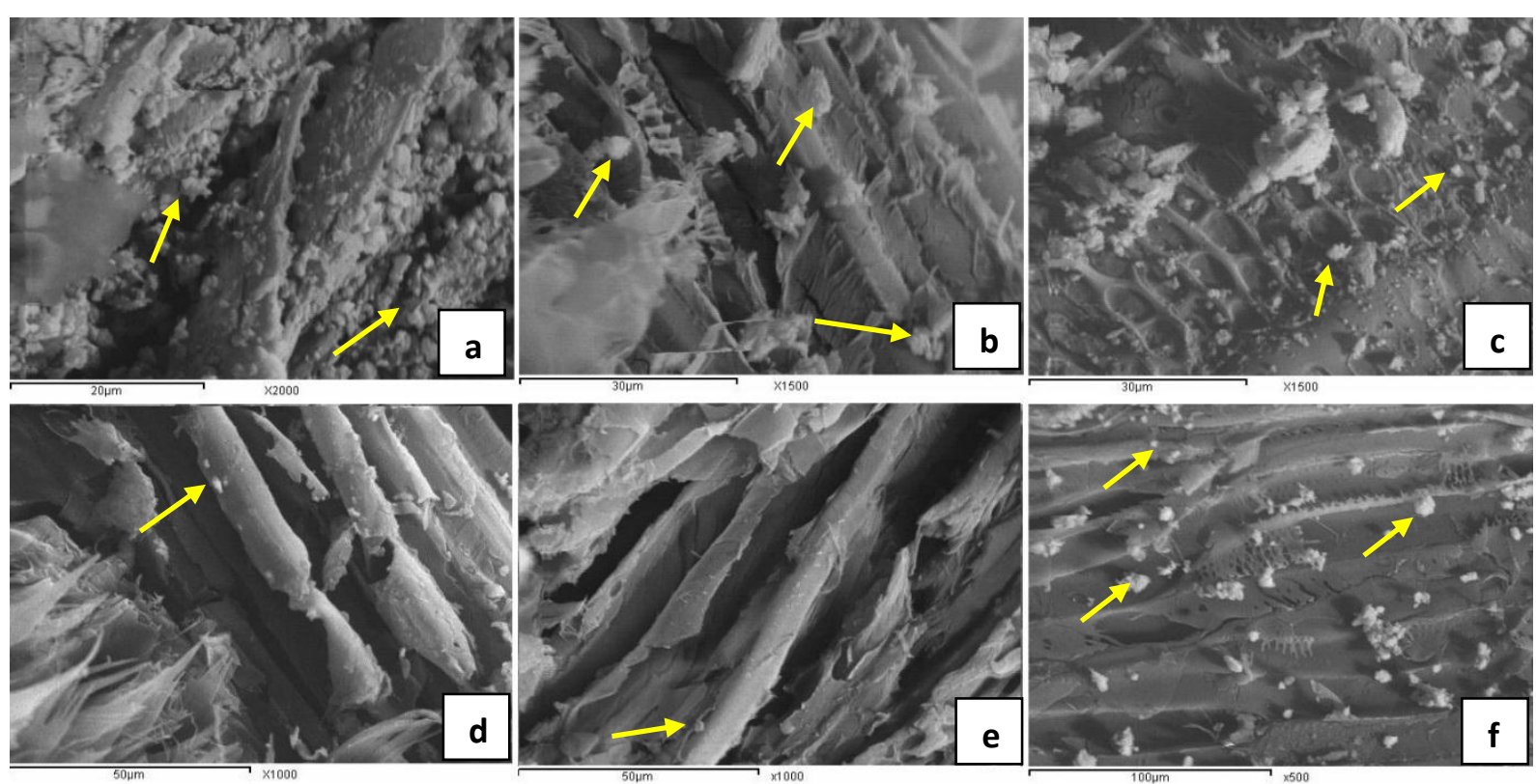

Fig. 1. SEM micrographs of Acacia wood samples taken from the surface directly below the different preparation layers, after natural aging and before exposure to accelerated aging, showing the penetration of preparation layers inside the wood (a) Acacia + chalk (b) Acacia + gypsum, (c) Acacia + chalk + gypsum, (d) Acacia + chalk + glue, (e) Acacia + gypsum + glue, (f) Acacia + chalk + gypsum + glue.
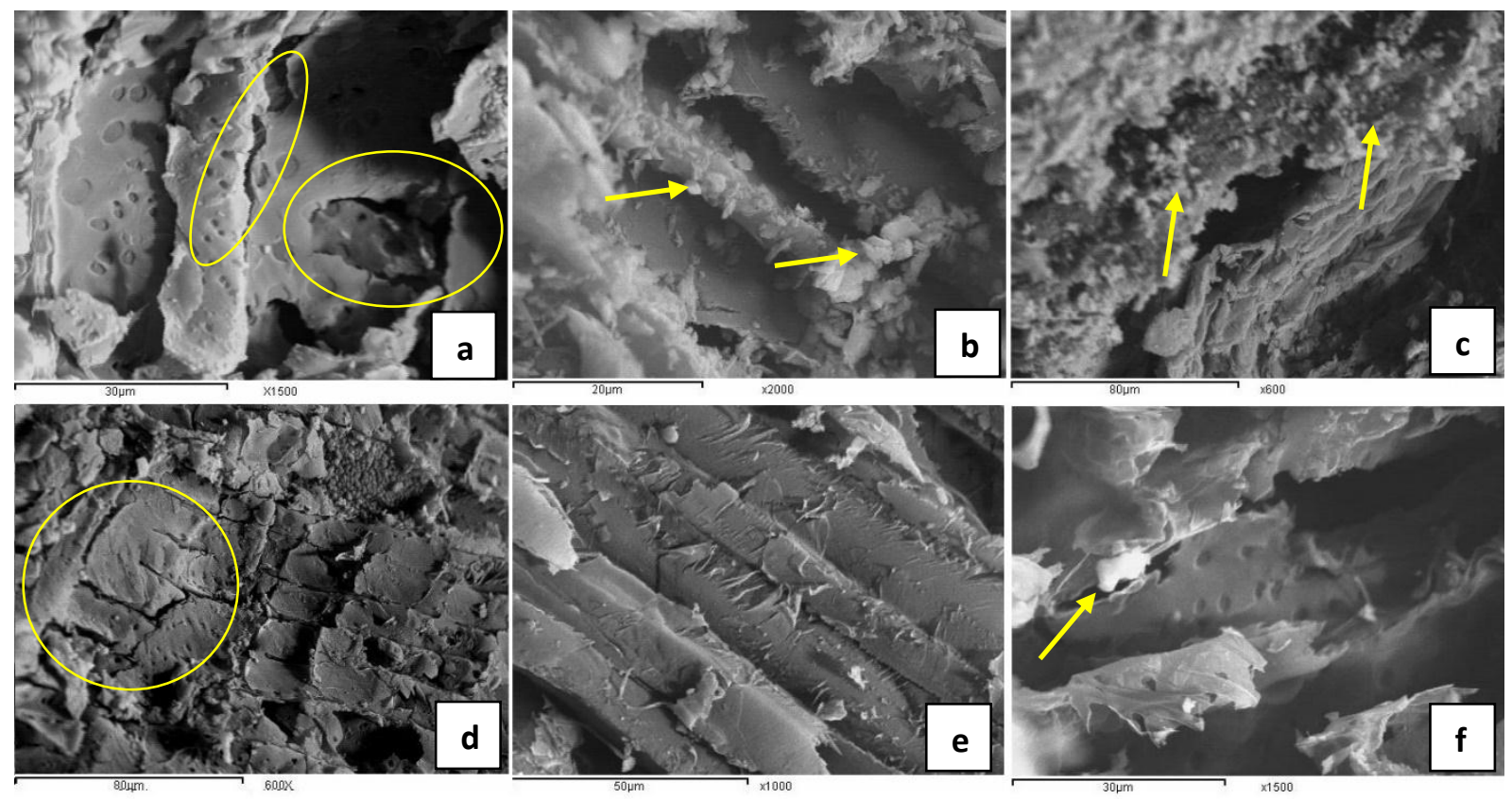

Fig. 2. SEM micrographs of sycomore wood taken from the surface directly below the different preparation layers, after natural aging and before exposure to accelerated aging, showing the penetration of preparation layers inside the wood (a) Sycomore + chalk (b) Sycomore + gypsum, (c) Sycomore + chalk + gypsum, (d) Sycomore + chalk + glue, (e) Sycomore + gypsum + glue, (f) Sycomore + chalk + gypsum+ glue. 

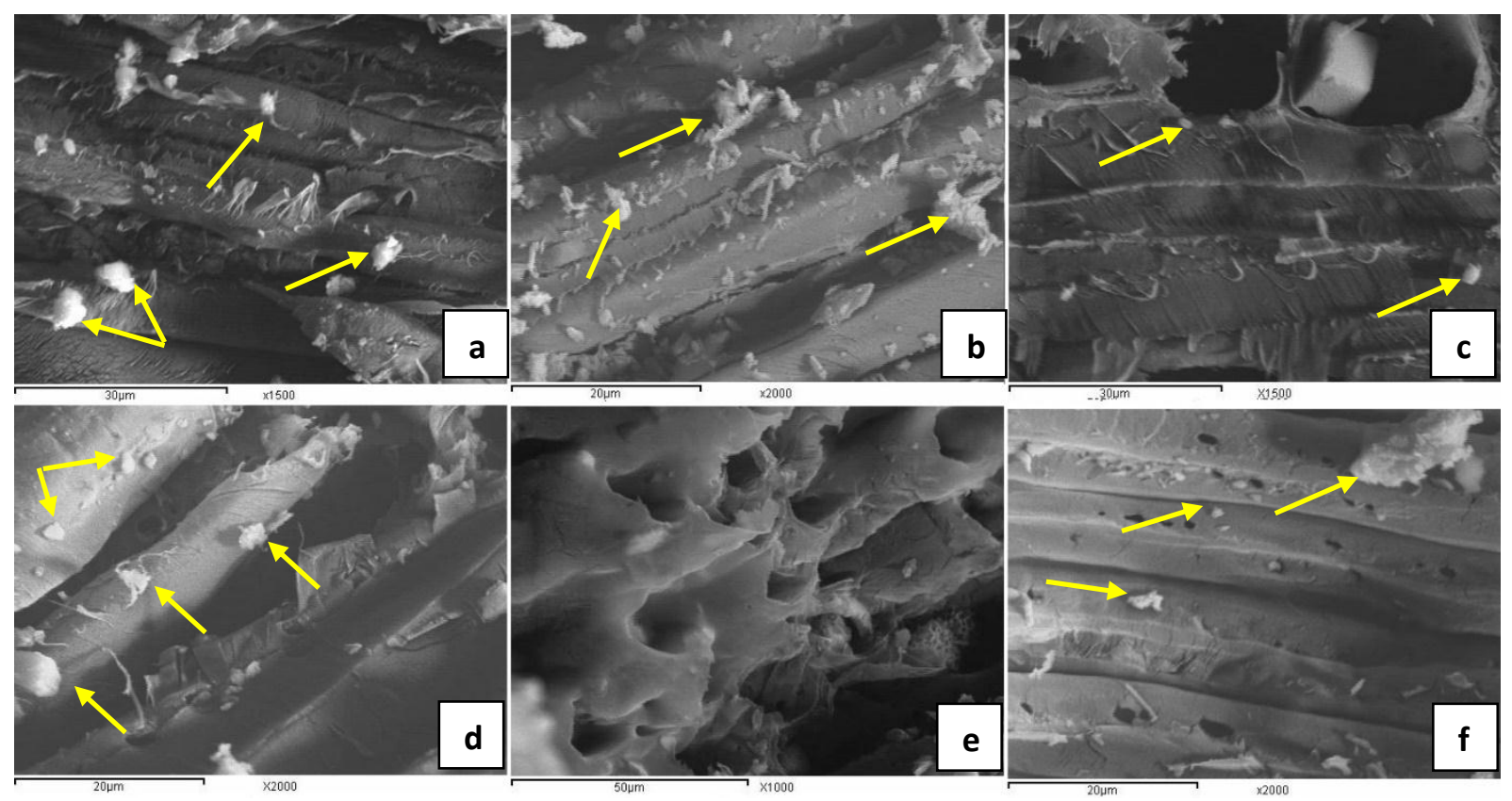

Fig. 3. SEM micrographs of Tamarix wood taken from the surface directly below the different preparation layers, after natural aging and before exposure to accelerated aging, showing the penetration of preparation layers inside the wood (a) Tamarix + chalk (b) Tamarix + gypsum, (c) Tamarix + chalk + gypsum, (d) Tamarix + chalk + glue, (e) Tamarix + gypsum + glue (f) Tamarix + chalk + gypsum+ glue.
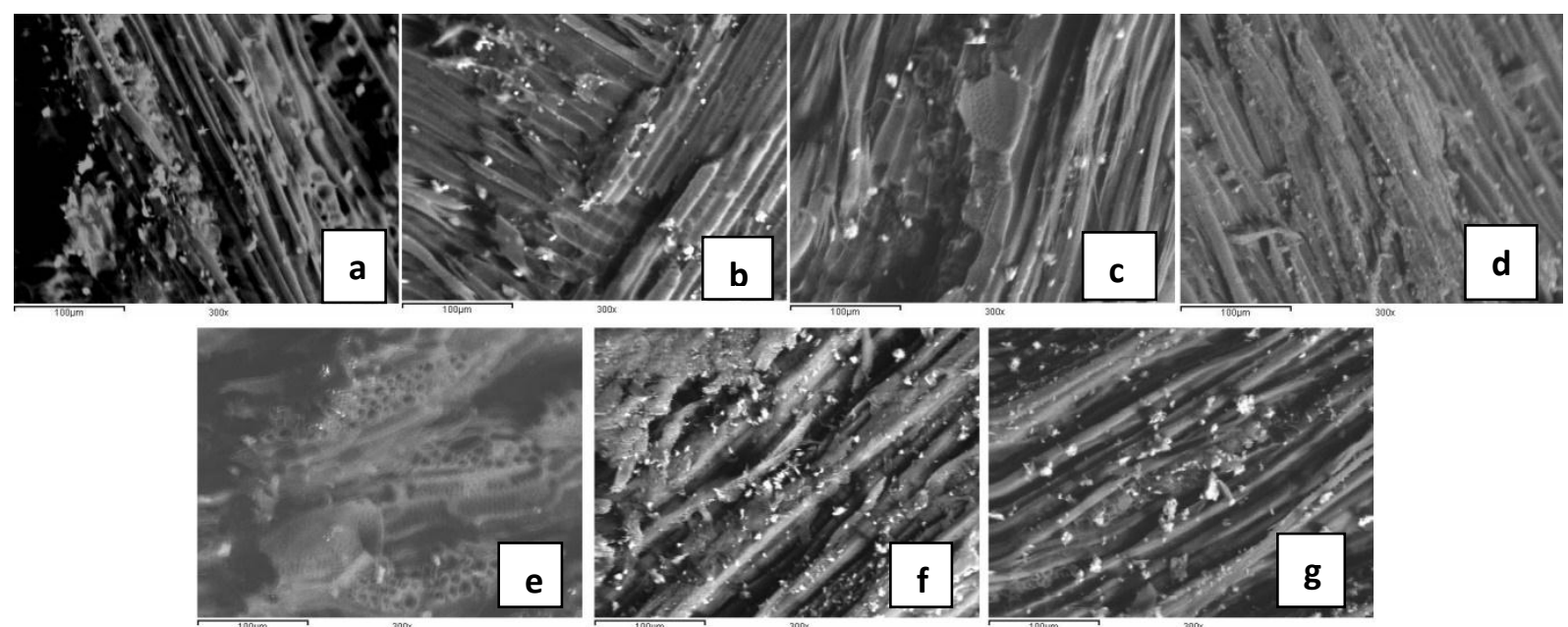

Fig. 4. SEM micrographs of acacia wood samples covered with different preparation layers, $5 \mathrm{~mm}$ directly below the substrate after exposure to natural and accelerated aging, showing penetration of preparation layers into the wood tissue and their precipitation on cell walls; (a) Control sample, (b) Acacia + chalk(c) Acacia + chalk + glue, (d) Acacia + gypsum, (e) Acacia + gypsum + glue (f) Acacia + chalk + gypsum, (g) Acacia + chalk + gypsum+ glue. 

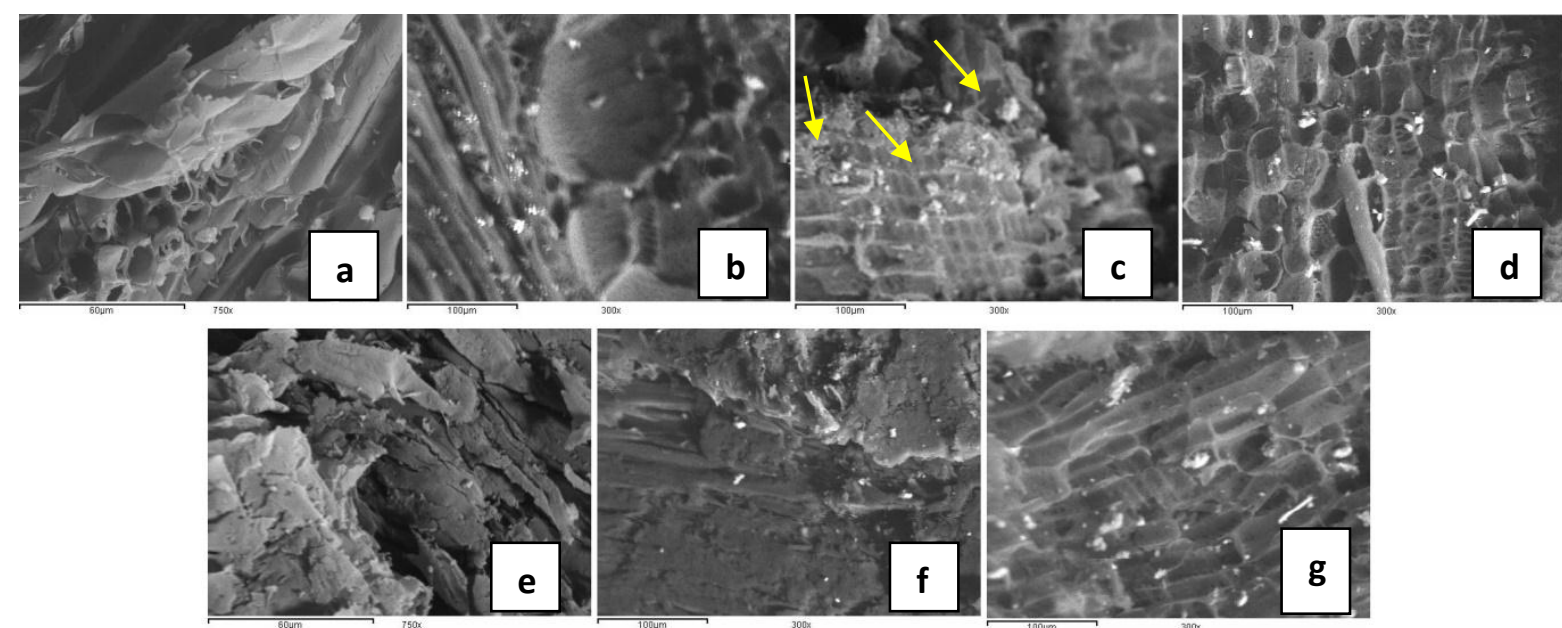

Fig. 5. SEM micrographs of Sycamore wood samples covered with different preparation layers, $5 \mathrm{~mm}$ directly below the substrate after exposure to natural and accelerated aging, showing penetration of preparation layers into the wood tissue and the decay of cell walls beneath them; (a) Control sample, (b) Sycomore + chalk(c) Sycomore + chalk + glue, (d) Sycomore + gypsum, (e) Sycomore + gypsum + glue (f) Sycomore + chalk + gypsum, (g) Sycomore + chalk + gypsum+ glue.
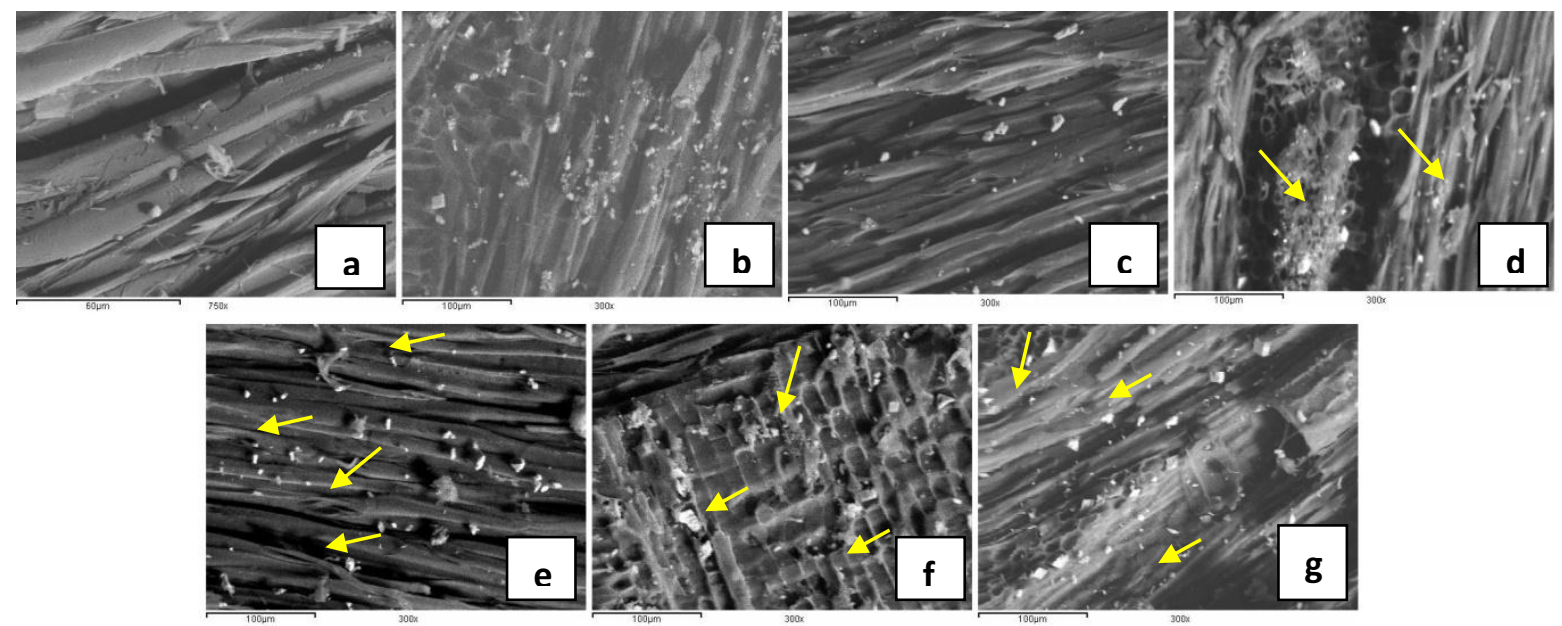

Fig. 6. SEM micrographs of Tamarix wood samples covered with different preparation layers, $5 \mathrm{~mm}$ directly below the substrate after exposure to natural and accelerated aging, showing almost similar penetration of preparation layers into the wood tissue; (a) Control sample, (b) Tamarix + chalk (c) Tamarix + chalk + glue, (d) Tamarix + gypsum, (e) Tamarix + gypsum + glue (f) Tamarix + chalk + gypsum, (g) Tamarix + chalk + gypsum+ glue. 


\subsection{Elemental analysis:}

EDX analyses were conducted on some spots where preparation layer particles were noticeable in SEM micrographs of wooden samples discussed above. The percentage of the four elements in the three different wood types with different preparation layers are a good indication of the penetration of the calcium carbonate and gypsum. Variation in percentage of carbon, oxygen, calcium and sulphur was stronger than all other elements detected in the analysis, and that is the reason why only these four major elements will be discussed here. The elemental comparison between the acacia samples are outlined in Fig. 7, table 1, sycomore samples in Fig. 8, table 2 and tamarix samples in Fig. 9, table 3.

\section{Comparing the three species of wood according to percentage of elements $\mathrm{C}, \mathrm{O}, \mathrm{S}$ and $\mathrm{Ca}$ :}

\section{Carbon (C):}

Least changes of carbon percentage where recorded in all the acacia wood samples. In the sycomore samples decrease occurred far stronger than the other two wood types and was strongest in the sample covered with chalk and glue. Decrease in the tamarix samples varied slightly, with the exception of a slight increase in the tamarix sample covered with gypsum and glue.

In all three wood types covered with preparation layers based on a mixture of chalk and gypsum the highest decrease of carbon percentage was noted; the lowest percentage of $\mathrm{C}$ was found in the tamarix wood sample covered with a mixture of chalk and gypsum based preparation layer.

\section{Oxygen $(O)$ :}

There was a slight increase of oxygen in all the acacia samples compared to the control sample. In the sycomore samples increase of oxygen percentages varied from one sample to the other.

In all cases, with exception of the tamarix sample covered with gypsum and glue, the $\mathrm{O}$ percentage increased in comparison to the control wood sample. The highest percentages of $\mathrm{O}$ were found in the tamarix wood sample covered with a mixture of chalk and gypsum based preparation layer, and in sycomore wood samples covered with a layer of chalk and glue.

In the tamarix sample the oxygen content varied, and both increase and decrease were obvious in different samples, in which the highest and lowest percentages of oxygen were recorded.

\section{Calcium (Ca):}

Acacia samples showed a slight increase of calcium in the samples covered with chalk, but a decrease was recorded in all samples covered with a layer containing gypsum.

The percentage of $\mathrm{Ca}$ element was significantly higher in sycomore compared to acacia and tamarix samples. Variable percentage increase in the sycomore samples was recorded; the highest percentage increase of calcium was in the sycomore wood covered with chalk and glue and the sycomore wood covered with a mixture of chalk and gypsum.

Calcium percentage was almost stable in the tamarix wood samples with the exception of the wood covered with a preparation layer composed of chalk and gypsum, in which a very high increase was measured. A minute decrease was noted in the two samples that were covered with a layer containing chalk and glue and the layer containing gypsum and glue.

In the previous study by El Hadidi and Hamed, 2017 [8], where sampling was done directly beneath the gesso substrate, prior to exposure to ageing, two main 


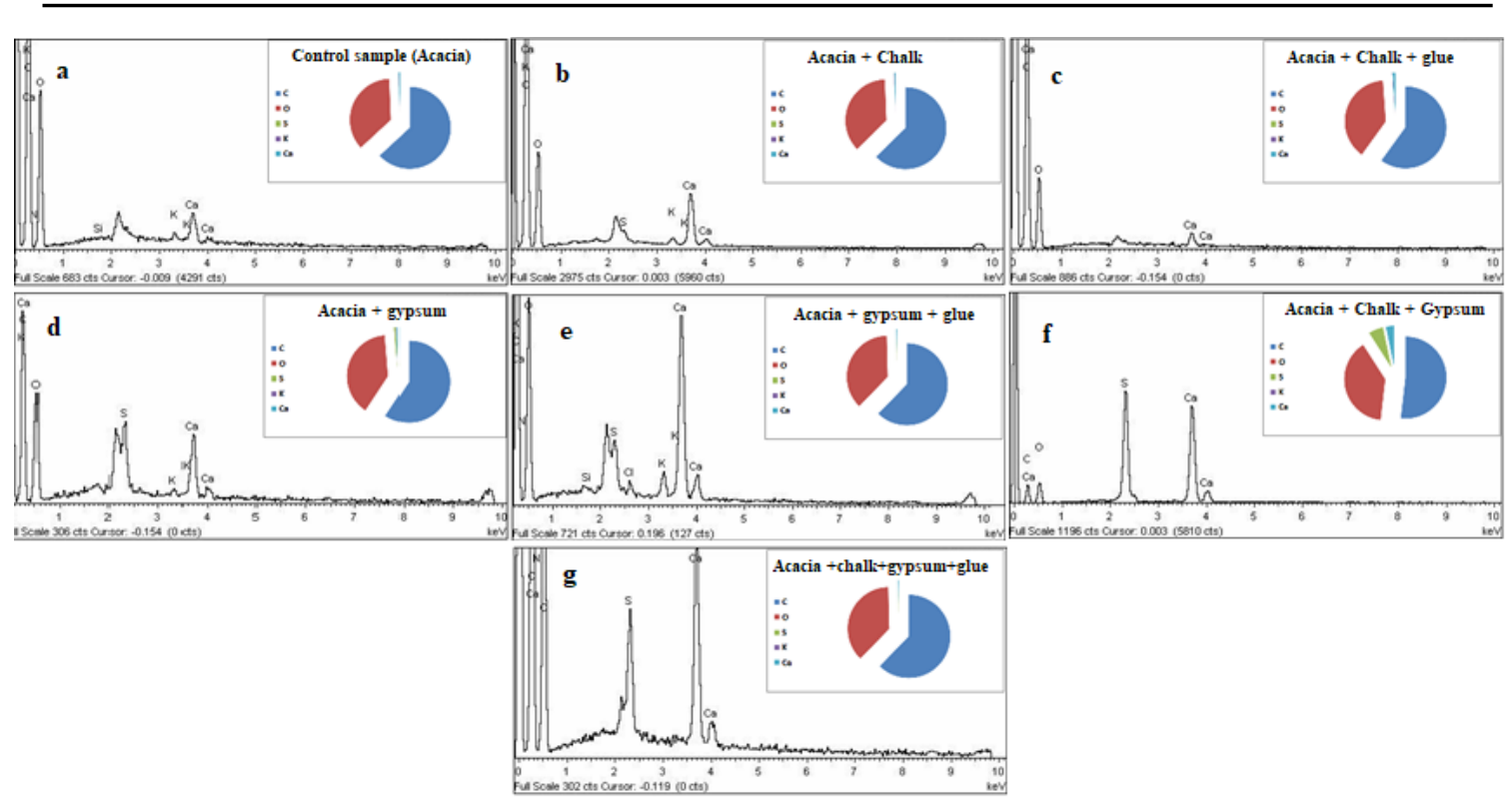

Fig. 7. EDX analysis of acacia wood samples revealing highest penetration of preparation layers containing calcium sulphate; (a) Control sample, (b) Acacia + chalk(c) Acacia + chalk + glue, (d) Acacia + gypsum, (e) Acacia + gypsum + glue (f) Acacia + chalk + gypsum, (g) Acacia + chalk + gypsum+ glue.

Table 1: Mean [ \pm standard deviation (SD)] elemental analysis of Acacia wood samples covered with different preparation layers.

\begin{tabular}{|c|c|c|c|c|c|c|c|}
\hline $\begin{array}{l}\text { Chemical } \\
\text { composition } \\
\text { (atomic \%) }\end{array}$ & $\begin{array}{l}\text { Control } \\
\text { sample } \\
\text { (Acacia) }\end{array}$ & $\begin{array}{c}\text { Acacia + } \\
\text { chalk }\end{array}$ & $\begin{array}{c}\text { Acacia + } \\
\text { chalk + } \\
\text { glue }\end{array}$ & $\begin{array}{l}\text { Acacia + } \\
\text { gypsum }\end{array}$ & $\begin{array}{l}\text { Acacia + } \\
\text { gypsum + } \\
\text { glue }\end{array}$ & $\begin{array}{l}\text { Acacia + } \\
\text { chalk } \\
\text { +gypsum }\end{array}$ & $\begin{array}{c}\text { Acacia + } \\
\text { chalk } \\
\text { +gypsum } \\
\text { + glue }\end{array}$ \\
\hline C & $62.87 \pm 3.09$ & $62.64 \pm 4.43$ & $58.43 \pm 0.32$ & $59.29 \pm 0.13$ & $62.24 \pm 5.97$ & $\underline{51.85 \pm 4.97}$ & $62.24 \pm 5.97$ \\
\hline 0 & $36.1 \pm 2.49$ & $36.66 \pm 4.43$ & $37.89 \pm 0.28$ & $39.45 \pm 0.68$ & $37.34 \pm 5.68$ & $\underline{39.09 \pm 0.33}$ & $37.34 \pm 5.68$ \\
\hline $\mathbf{S}$ & $0.01 \pm 0.01$ & $0.01 \pm 0.01$ & $0.01 \pm 0.01$ & $0.71 \pm 0.05$ & $0.11 \pm 0.16$ & $\underline{5.79 \pm 1.08}$ & $0.11 \pm 0.16$ \\
\hline $\mathrm{Ca}$ & $0.57 \pm 0.63$ & $0.55 \pm 0.05$ & $0.96 \pm 0.55$ & $0.50 \pm 0.56$ & $0.31 \pm 0.13$ & $\underline{3.27 \pm 4.23}$ & $0.31 \pm 0.13$ \\
\hline $\mathbf{N}$ & $0.21 \pm 0.06$ & $\mathbf{0}$ & $2.35 \pm 0.76$ & $\mathbf{0}$ & $\mathbf{0}$ & $\mathbf{0}$ & $\mathbf{0}$ \\
\hline Si & $0.03 \pm 0.02$ & $0.08 \pm 0.06$ & $0.16 \pm 0.13$ & $\mathbf{0}$ & $\mathbf{0}$ & $\mathbf{0}$ & $\mathbf{0}$ \\
\hline $\mathrm{Cl}$ & $\mathbf{0}$ & $\mathbf{0}$ & $0.07 \pm 0.01$ & $\mathbf{0}$ & $\mathbf{0}$ & $\mathbf{0}$ & $\mathbf{0}$ \\
\hline K & $0.07 \pm 0.02$ & $0.07 \pm 0.02$ & $0.15 \pm 0.04$ & $0.07 \pm 0.03$ & $\mathbf{0}$ & $0.02 \pm 0.02$ & $\mathbf{0}$ \\
\hline
\end{tabular}

Underline indicates significant differences at $P$-value $<0.05$ when compared among the same element vs. control sample. 


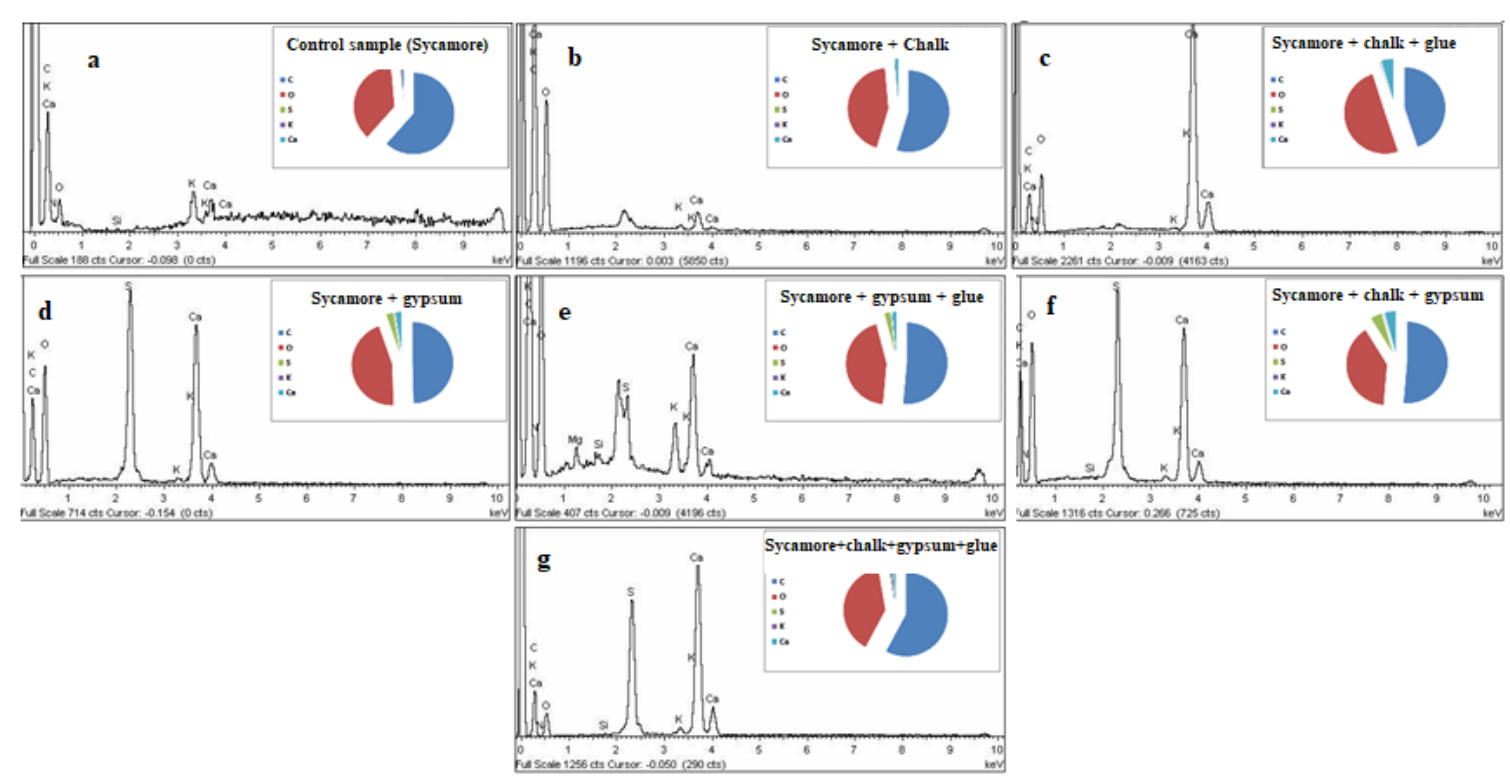

Fig. 8. EDX analysis of Sycomore wood samples covered with different preparation layers, showing high percentage of Sulphur in wood due to penetration of preparation layers containing gypsum; (a) Control sample, (b) Sycomore + chalk(c) Sycomore + chalk + glue, (d) Sycomore + gypsum, (e) Sycomore + gypsum + glue (f) Sycomore + chalk + gypsum, (g) Sycomore + chalk + gypsum+ glue.

Table 2: Mean $( \pm$ SD) element analysis of Sycomore wood samples covered with different preparation layers.

\begin{tabular}{|c|c|c|c|c|c|c|c|}
\hline $\begin{array}{l}\text { Chemical } \\
\text { composition } \\
\text { (atomic \%) }\end{array}$ & $\begin{array}{l}\text { Control } \\
\text { sample (Sy- } \\
\text { comore) }\end{array}$ & $\begin{array}{l}\text { Sycomore } \\
+ \text { chalk }\end{array}$ & $\begin{array}{l}\text { Sycomore } \\
+ \text { chalk + } \\
\text { glue }\end{array}$ & $\begin{array}{l}\text { Sycomore } \\
+ \text { gypsum }\end{array}$ & $\begin{array}{l}\text { Sycomore } \\
+ \text { gypsum } \\
+ \text { glue }\end{array}$ & $\begin{array}{l}\text { Sycomore } \\
+ \text { chalk } \\
\text { +gypsum }\end{array}$ & $\begin{array}{l}\text { Sycomore } \\
+ \text { chalk } \\
\text { +gypsum + } \\
\text { glue }\end{array}$ \\
\hline $\mathrm{C}$ & $56.77 \pm 1.36$ & $54.62 \pm 5.93$ & $\underline{44.10 \pm 18.40}$ & $49.52 \pm 11.59$ & $50.57 \pm 8.38$ & $49.47 \pm 12.27$ & $56.75 \pm 2.36$ \\
\hline $\mathbf{0}$ & $34.12 \pm 5.35$ & $43.85 \pm 4.15$ & $\underline{49.39 \pm 12.76}$ & $44.96 \pm 7.33$ & $43.66 \pm 5.12$ & $38.21 \pm 14.19$ & $38.68 \pm 2.12$ \\
\hline $\mathbf{S}$ & $0.01 \pm 0.01$ & $0.01 \pm 0.01$ & $0.10 \pm 0.15$ & $2.80 \pm 2.49$ & $2.36 \pm 2.01$ & $\underline{4.29 \pm 0.18}$ & $0.47 \pm 0.22$ \\
\hline $\mathrm{Ca}$ & $0.53 \pm 0.25$ & $1.27 \pm 1.46$ & $\underline{4.61 \pm 5.73}$ & $2.44 \pm 2.10$ & $1.54 \pm 1.30$ & $4.16 \pm 2.25$ & $1.20 \pm 1.07$ \\
\hline $\mathbf{N}$ & $7.77 \pm 5.86$ & $\mathbf{0}$ & $1.52 \pm 0.35$ & $0.09 \pm 0.15$ & 0 & $2.79 \pm 1.11$ & $1.89 \pm 2.67$ \\
\hline Mg & $\mathbf{0}$ & $0.16 \pm 0.22$ & $0.12 \pm 0.16$ & $\mathbf{0}$ & $0.04 \pm 0.07$ & $\mathbf{0}$ & $\mathbf{0}$ \\
\hline Si & $0.05 \pm 0.00$ & $\mathbf{0}$ & $0.02 \pm 0.02$ & $\mathbf{0}$ & $0.02 \pm 0.01$ & $0.03 \pm 0.00$ & $0.01 \pm 0.01$ \\
\hline $\mathrm{Cl}$ & $0.04 \pm 0.06$ & $\mathbf{0}$ & $\mathbf{0}$ & $\mathbf{0}$ & $\mathbf{0}$ & $\mathbf{0}$ & $\mathbf{0}$ \\
\hline $\mathbf{K}$ & $0.73 \pm 0.64$ & $0.12 \pm 0.10$ & $0.16 \pm 0.11$ & $0.14 \pm 0.14$ & $0.12 \pm 0.07$ & $0.14 \pm 0.07$ & $1.01 \pm 1.16$ \\
\hline
\end{tabular}

Underline indicates significant differences at $P$-value $<0.05$ when compared among the same element vs. control sample. 


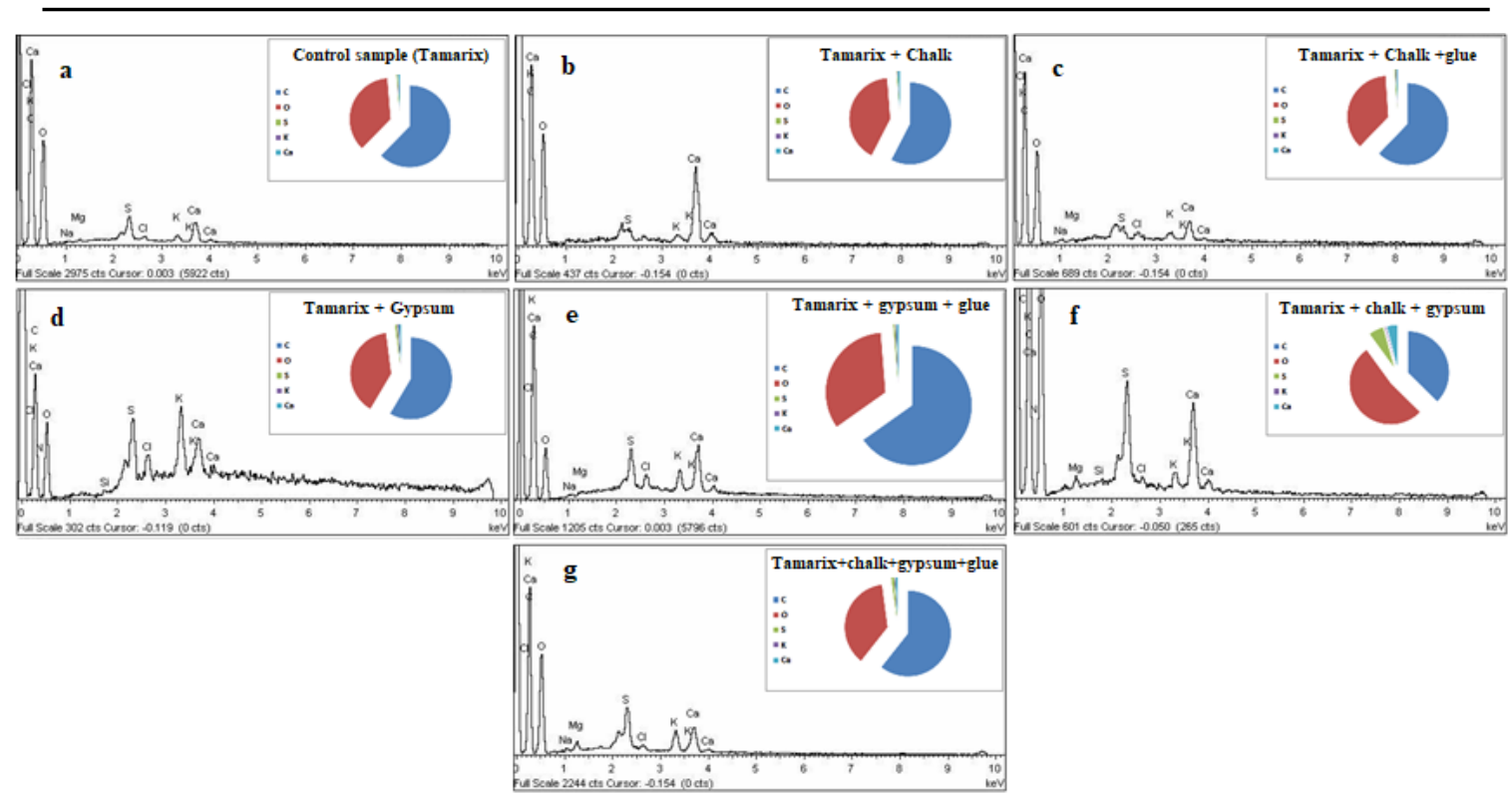

Fig. 9. EDX analysis of Tamarix wood samples covered with different preparation layers,showing presence of same elements in all samples but with different percentage based on the chemical composition of preparation layers; (a) Control sample, (b) Tamarix + chalk (c) Tamarix + chalk + glue, (d) Tamarix + gypsum, (e) Tamarix + gypsum + glue (f) Tamarix + chalk + gypsum, (g) Tamarix + chalk + gypsum+ glue.

Table 3: Mean $( \pm$ SD) element analysis of Tamarix wood samples covered with different preparation layers.

\begin{tabular}{|c|c|c|c|c|c|c|c|}
\hline $\begin{array}{l}\text { Chemical } \\
\text { composition } \\
\text { (atomic \%) }\end{array}$ & $\begin{array}{l}\text { Control } \\
\text { sample } \\
\text { (Tamarix) }\end{array}$ & $\begin{array}{l}\text { Tamarix + } \\
\text { chalk }\end{array}$ & $\begin{array}{l}\text { Tamarix }+ \\
\text { chalk }+ \\
\text { glue }\end{array}$ & $\begin{array}{l}\text { Tamarix + } \\
\text { gypsum }\end{array}$ & $\begin{array}{l}\text { Tamarix + } \\
\text { gypsum + } \\
\text { glue }\end{array}$ & $\begin{array}{l}\text { Tamarix + } \\
\text { chalk } \\
\text { +gypsum }\end{array}$ & $\begin{array}{l}\text { Tamarix + } \\
\text { chalk } \\
\text { +gypsum } \\
+ \text { glue }\end{array}$ \\
\hline $\mathrm{C}$ & $62.15 \pm 6.59$ & $57.52 \pm 1.63$ & $61.91 \pm 3.64$ & $55.83 \pm 3.07$ & $64.99 \pm 6.96$ & $\underline{37.24 \pm 4.62}$ & $60.40 \pm 1.58$ \\
\hline 0 & $36.17 \pm 6.40$ & $41.18 \pm 1.58$ & $36.59 \pm 4.53$ & $37.60 \pm 2.86$ & $33.40 \pm 7.95$ & $\underline{52.32 \pm 2.73}$ & $37.08 \pm 2.58$ \\
\hline S & $0.44 \pm 0.19$ & $0.32 \pm 0.27$ & $0.42 \pm 0.50$ & $0.79 \pm 0.21$ & $0.47 \pm 0.21$ & $\underline{5.72 \pm 2.98}$ & $1.08 \pm 0.66$ \\
\hline $\mathrm{Ca}$ & $0.69 \pm 0.36$ & $0.81 \pm 0.46$ & $0.51 \pm 0.25$ & $0.68 \pm 0.07$ & $0.57 \pm 0.37$ & $\underline{3.92 \pm 3.83}$ & $0.79 \pm 0.59$ \\
\hline $\mathbf{N a}$ & $0.13 \pm 0.09$ & - & $0.12 \pm 0.06$ & $0.13 \pm 0.11$ & $0.11 \pm 0.06$ & $0.28 \pm 0.39$ & $0.10 \pm 0.13$ \\
\hline Mg & $0.15 \pm 0.04$ & $0.07 \pm 0.10$ & $0.08 \pm 0.03$ & $0.11 \pm 0.09$ & $0.08 \pm 0.01$ & $0.08 \pm 0.11$ & $0.22 \pm 0.07$ \\
\hline Si & - & $0.01 \pm 0.01$ & - & $0.08 \pm 0.02$ & - & $0.06 \pm 0.08$ & $0.00 \pm 0.00$ \\
\hline $\mathrm{Cl}$ & $0.09 \pm 0.01$ & $0.02 \pm 0.03$ & $0.23 \pm 0.16$ & $0.24 \pm 0.24$ & $0.17 \pm 0.13$ & $0.05 \pm 0.06$ & $0.09 \pm 0.01$ \\
\hline K & $0.19 \pm 0.09$ & $0.09 \pm 0.01$ & $0.16 \pm 0.09$ & $0.49 \pm 0.51$ & $0.23 \pm 0.19$ & $0.34 \pm 0.24$ & $0.24 \pm 0.10$ \\
\hline
\end{tabular}

Underline indicates significant differences at $P$-value $<0.05$ when compared among the same element vs. control sample. 
points were noted in the samples treated with either chalk or chalk and glue; namely the occurrence of lignin degradation, which resulted in the degradation of the cell walls, and the strengthening of the calcium carbonate bands in the FTIR spectra. This may partially help explain the penetration of calcium in the three wood types, in addition to the different dimensions of the cells types in three wood types.

\section{Sulphur (S):}

Acacia and sycomore control samples contained an extremely small percentage of sulphur that can almost be ignored, on the contrary to the tamarix control sample which initially contained S. A variable increase in $\mathrm{S}$ percentage was recorded in all samples covered with preparation layers containing gypsum in general, and reached the highest percentage in the case of chalk and gypsum based preparation layer. The percentage of $S$ dropped in all the samples covered with a mixture of chalk, gypsum and glue.

According to El Hadidi and Hamed, 2017 [8] degradation occurred in the cell walls of the samples that had been treated with gypsum and the FTIR spectra showed the presence of prominent lignin bands and the main sulphate bands. These previous findings agree with the current results, which recorded the variable percentages of sulphur according to the gesso layer composition.

Changes of potassium percentage are negligible in most cases with exception of the sycomore control sample, the sycomore sample covered with a mixture of chalk, gypsum and glue, and the tamarix sample covered with gypsum, where a high percentage was recorded. The rest of the elements recorded during analyses were not always found in all samples and their percentages were extremely low and are of no significance.

Reaching a final conclusion/explanation for these changes is difficult, because in previous research the elemental analysis of ancient native or imported wood types is rarely found. By coincidence two studies on ancient Cupressus sempervirens (cypress wood) with and without preparation layers were conducted in which the elemental analysis was performed. In both papers the calcium and sulphur percentage was much higher than the percentage recorded in the three native wood types $[15,16]$.

\section{Conclusions}

In the present study, SEM-EDX investigations were used to examine and compare the penetration depth of preparation layers inside three types of wood (Acacia, Sycomore, and Tamarix) covered with six different preparation layers. The results of this study found significant differences in penetration ratio according to the wood type, porosity and the mineralogical composition of the preparation layer applied on its surface. The penetration of preparation layer particles within wood structure was much higher in sycomore wood in comparison to acacia and tamarix wood samples as was shown microscopically and proven by the highest variation in percentage of the four elements $(\mathrm{C}, \mathrm{O}, \mathrm{S}, \mathrm{Ca})$, which occurred in the sycomore samples, that are very porous in comparison to the other two wood types. All types of preparation layers penetrated within the three types of wood, The resulting deterioration was clearly apparent in the samples covered with gypsum-based layers and mixture of chalk and gypsum-based layers, where the highest increase in percentage of oxygen, calcium and sulphur and the strongest decrease in carbon occurred in both tamarix and acacia wood samples that were covered with a preparation layer composed of a mixture of chalk and gypsum. Variation trends in both acacia and tamarix samples were slightly similar to each other, but were very different from the sycomore samples. The differ- 
ences that were found among the three species of wood; acacia, sycomore and tamarix, is mainly related to structure and chemical composition. Further research can be done to either study the penetration of other types of preparation layers, or the same preparation layers, but of different coarseness on other types of wood, with different anatomical features and chemical composition. For conservators it may also be interesting to try and study how consolidants, with different viscosities would penetrate preparation layers with different components and thicknesses.

\section{References}

1. P. K. Larsen, Climate control in Danish churches, Museum Microclimates, T. Padfield \& K. Borchersen (eds.) National Museum of Denmark, 2007. http://www.conservationphysics.org/ $\mathrm{mm} /$ larsen/larsen.pdf .

2. C. B. Böhm, C.B., Zehnder, K., Domeisen, H. And Arnold, A., Climate control for the passive conservation of the romanesque painted wooden ceiling in the church of Zillis (Switzerland), Studies in Conservation, Vol. 46, No. 4, 2001, pp. 251-268. https://doi.org/10.1179/sic.2001.46.4 .251.

3. A. Chan, Preservation and restoration of timber heritage structures, International Specialised Skills Institute (ISS institute Inc), Melbourne, 2011. http://www.issinstitute.org.au/wpcontent/media/2011/03/ISS-FELREPORT-A-CHAN-low-res.pdf

4. R. A. Stein, P. Lacovara, Observations on the preparation layers found on ancient Egyptian decorated coffins in the Michael C. Carlos Museum. In Decorated surfaces on ancient Egyptian objects, Dawson, J., Rozeik, C., Wright, M. M.(Eds.), (Technology, deteriora- tion and conservation). Archetype Publications, London, 2010, pp. 3-8.

5. M. Romagnoli, M. Sarlatto, F. Terranova, E. Bizzarri, S. Cesetti, Wood identification in the Cappella Palatina ceiling (12th century) in in Palermo (Sicily, Italy), IAWA Journal, Vol. 28, No. 2, 2007, pp. 109-123. http://booksandjournals.brillonline.co $\mathrm{m} /$ content/journals/10.1163/229419 32-90001628

6. H. Afifi, S. A. M. Hamed, S. Mohamedy, M. Dawod, A dating approach of a refundable wooden Egyptian coffin lid, SCIENTIFIC CULTURE, Vol. 5, No. 1, 2019, pp. 15-2 2.

https://sci-cult.com/wp-

content/uploads/5.1/5 12 Afifi-et-

al.pdf

7. I. D. Gourlay, G. W. Grime, Calcium oxalate crystals in African Acacia species and their analysis by Scanning Proton Microprobe (SPM), IAWA Journal, Vol. 15, No. 2, 1994, pp.137148.

https://doi.org/10.1163/2294193290001353

8. N. M. N. El Hadidi, S. A. M. Hamed, The effect of Preparation layers on the Anatomical Structure and Chemical Composition of Native Egyptian Wood, In: Amenta, A. and Guichard, H. (eds.), Proceedings First Vatican Coffin Conference, Vatican Museums Conference Hall, 19 - 22 June 2013, Vol. I, Edizioni Musei Vaticani, 2017, pp.199-210.

http://scholar.cu.edu.eg/sites/default /files/asjm/files/the_effect_of_prepar ation_layers_on_the_anatomical_stru cture_and_chemical_composition_of _wood.pdf

9. Y. Zidan, N. M. N. El Hadidi, O. A. Ebeid, Documentation of the second boat of Abu Rawash, Archaeological Sites and Museum Collections, Values, Problems and Solutions, Faculty 
of Archaeology, Cairo University, October 2015 (in Arabic).

10. N. M. N. El Hadidi, The Cheops Boat - 50 Years Later, in Conservation of Historic Wooden Structures Vol. 1, Florence, Italy, 2005, pp. 452-457.

https://scholar.cu.edu.eg/?q=nesrin/p ublications/cheops-boat$\%$ E2\%80\%93-50-years-later

11. A. T. J. Ogunkunle, F. A Oladele, Contributions to classification of some Nigerian species of Ficus L. (Moraceae) by using wood anatomical characteristics, Journal of Plant Biology Research, Vol. 3, No. 1, 2014, pp. 23-36.

http://www.inast.org/issue $\% 2009 \%$ 202014/3-

R070114\%20final\%20proof.pdf

12. N. M. Waly, H. M. Emad, Taxonomical Studies of Some Acacia spp. Growing in Saudi Arabia, Bulletin of Environment, Pharmacology and Life Sciences, Vol. 1, No. 10, 2012, pp.55-62.

http://www.bepls.com/sept_2012/1 1.pdf.

13. K. Mahmood, A. R. Awan, M. I. Chughtai, Anatomical, Physical and Mechanical Properties of Salt Tolerant Tree Species Grown in Punjab, Pakistan, Pak. J. Bot., Vol. 48, No. 5, 2016, pp. 1813-1818. http://www.pakbs.org/pjbot/PDFs/4 8(5)/07.pdf.
14. K. E. Medley, Extractive forest resources of the Tana River National Primate Reserve, Kenya Economic Botany, Vol. 47, No. 2, 1993, pp. 171-183.

The New York Botanical Garden, Bronx, NY $10458 \quad$ U.S.A. https://www.jstor.org/stable/42555 02

15. N. Bader, W. Al-Gharib, Assessment of deterioration and conservation of a polychrome wooden coffin from Al-Arish Museum, Egypt". International Journal of Conservation Science, Vol. 4, 2013, pp.397-412. http://www.ijcs.uaic.ro/public/IJCS13-38-Bader.pdf.

16. N.M.N. El Hadidi, S. Darwish, Preliminary study on the different effects of consolidation treatments in heartwood and sapwood of a decayed gymnosperm wood, Egyptian Journal of Archaeological and Restoration Studies "EJARS", Vol. 4,No. 1, 2014, pp. 1-11. http://ejars.sohaguniv.edu.eg/IssueFullText?q=41. 